\title{
Prioritering - er alle gode ting bare tre?
}

\author{
Prioriteringer i helsetjenesten skal baseres på tre kriterier: alvorlighetsgrad av tilstanden, nytte og kostnads- \\ effektivitet. Disse kriteriene ble etablert av Lønning-utvalgene, men er de fortsatt tilstrekkelige?
}

\author{
Hege Wang \\ hew@nokc.no \\ Siv Cathrine Høymork
}

Gapet mellom ønsker og ressurser er en utfordring i fordelingen av offentlige velferdsgoder. Ivar Aasen skrev i sin tid at «Til lags åt alle kan ingen gjera, det er no gamalt og vil so vera» (1). Helsetjenestens muligheter har økt betydelig siden den gang. Det er et stadig press om å øke innsatsen med flere tjenester, ny teknologi, nye legemidler, nye tester og nye forebyggende tiltak. Prioritering mellom ulike grupper og tiltak blir dermed nødvendig. Samtidig er et likeverdig tilbud til alle et grunnleggende prinsipp for den offentlige helsetjenesten (2). Hvilke kriterier som blir vektlagt når ressursene fordeles, har stor betydning for om tjenestene fordeles på en måte som oppfattes som rettferdig og likeverdig.

\section{Utvikling av prioriteringskriterier}

I den forste offentlige utredningen om prioritering, som ble levert av Lønning Iutvalget i 1987, ble det lagt vekt på tilstandens alvorlighet, i tråd med sunt folkevett og en pliktetisk tilnærming (3). Ivar Aasen sa det slik: «Eg tykkjer støtt at det høver best, å hjelpa den som det trengjer mest» (1). I den neste offentlige prioriteringsutredningen, Lønning II-utvalget i 1997, ble tiltakets nytte og kostnadseffektivitet tillagt større vekt enn før (4). Kriterier om effekt av tiltak og kostnadseffektivitet ble lagt til. Dette kan sies å avspeile en utvikling fra hovedvekt på pliktetikk til også vektlegging av nytteetisk tenkning (5). Nylig ble det utnevnt et tredje offentlig utvalg for prioritering i helsetjenesten, Norheimutvalget, som skal vurdere om det er behov for flere eller andre prioriteringskriterier (6).

\section{Nasjonalt prioriteringsråd}

Nasjonalt råd for kvalitet og prioritering $i$ helse- og omsorgstjenesten (Nasjonalt råd) ble opprettet i 2007 (7). Rådet gir anbefalinger til helsetjenesten, forvaltningen og politiske myndigheter. Transparens og åpenhet er viktig i dette arbeidet. Møtene er åpne for publikum og presse, og møte- referater og vedtak publiseres. De tre prioriteringskriteriene ligger til grunn for saksutredning og diskusjon, men setter ikke begrensninger for diskusjonene. Vi har sett på hvilke andre argumenter og prinsipper som blir trukket frem i rådets diskusjoner.

\section{Alder og arbeidsevne}

Ifølge dagens kriterier skal kostnader stå $i$ et rimelig forhold til tiltakets effekt. I forbindelse med drøfting av nye og svært kostbare kreftlegemidler og eventuelle grenseverdier for kostnadseffektivitet, ble det argumentert for at pasientens alder burde

\section{«Gode prinsipper og kriterier for priorite- ring gir bedre fordeling og mer rettferdighet»}

vektlegges: Samfunnet bør være villig til å betale mer for ekstra levetid hos yngre mennesker. Lønning II-utvalget åpnet ikke for å legge vekt på pasientens alder som et selvstendig kriterium.

Det har vært vanlig å bruke et helsetjenesteperspektiv i økonomiske analyser av tiltak i helsetjenesten. Tiltak i helsetjenesten kan imidlertid påvirke økonomien $i$ andre sektorer, og Helsedirektoratets veileder i økonomisk evaluering av helsetiltak fra 2012 anbefaler å bruke et samfunnsperspektiv (8).

Denne problematikken tok Nasjonalt råd i saken om innføring av vaksine mot rotavirusinfeksjon i barnevaksinasjonsprogrammet. Det gjorde et stort utslag om foreldres fravær fra jobb ble tatt med i de helseøkonomiske analysene eller ikke. Rådet argumenterte med å legge vekt på gevinsten av redusert sykefravær blant foreldrene så lenge vaksinen også var et gode for barna. Skal tiltak som påvirker arbeidsevnen prioriteres, og bør arbeidsføre komme frem i køen? Det er for øvrig interessant at ordningen «Raskere tilbake», som ble etablert i 2007, er tuftet på arbeidsevne som eneste prioriteringskriterium (9). Ordningen ser dermed ut til å være i strid med anbefalingene i Løn- ning II-utredningen, som påpeker at prioritering på gruppenivå etter produksjonshensyn vil være et brudd med likeverdighetsprinsippet.

\section{$\emptyset$ nsker, likeverdige tjenester og livskvalitet}

Utredningen som lå til grunn for rådets diskusjoner om tidlig ultralyd i svangerskapet, inneholdt en gjennomgang av helsefaglige, etiske og økonomiske forhold (10). Rådsleders forslag til vedtak tok utgangspunkt i de etablerte prioriteringskriteriene. Det var ikke påvist at rutinemessig tidlig ultralyd ville medføre noen helseeffekt for mor eller barn, og leder foreslo derfor at tiltaket ikke ble tilbudt som en del av den offentlige helsetjenesten. I diskusjonen kom det frem at noen mente dette var for snevre perspektiver. Det ble pekt på at om lag halvparten av gravide i dag utfører en slik undersøkelse og at det offentlige tilbyr tidlig ultralyd til gravide over 38 år. Det ble lagt frem et alternativt vedtaksforslag, og etter avstemning gikk flertallet i rådet inn for å etablere et offentlig tilbud om tidlig ultralyd i svangerskapet. Her kan det altså se ut som om pasientenes ønsker og den overordnede verdien om likeverdige tjenester ble tillagt større vekt enn de tre etablerte kriteriene. Nasjonalt råd har også i andre saker tillagt pasientenes ønsker og opplevd livskvalitet stor vekt, for eksempel i sakene om rekonstruksjon etter brystkreft (11) og behandlingsreiser til utlandet (12).

\section{Sjeldenhet og budsjettkonsekvenser} Nasjonalt råd har prinsipielt tatt til orde for at sjeldne tilstander ikke skal gis annen prioritet enn vanlige sykdommer (13). I praksis kan det imidlertid synes noe annerledes. I en sak om mekaniske, bærbare hjertepumper åpnet Nasjonalt råd for å ta i bruk hjertepumper som varig behandling, til tross for lav kostnadseffektivitet (14). I vedtaket fremheves det at bare få pasienter vil trenge slik behandling. Det kan dermed synes som om forventede budsjettimplikasjoner tillegges vekt. En gjennomgang av refusjonsvedtak viser at pasienter med sjeldne sykdommer får refundert langt dyrere legemidler enn pasienter med vanligere sykdommer, og rådsmedlem Robberstad mener dette er problematisk (15). Heiberg og medarbeidere, 


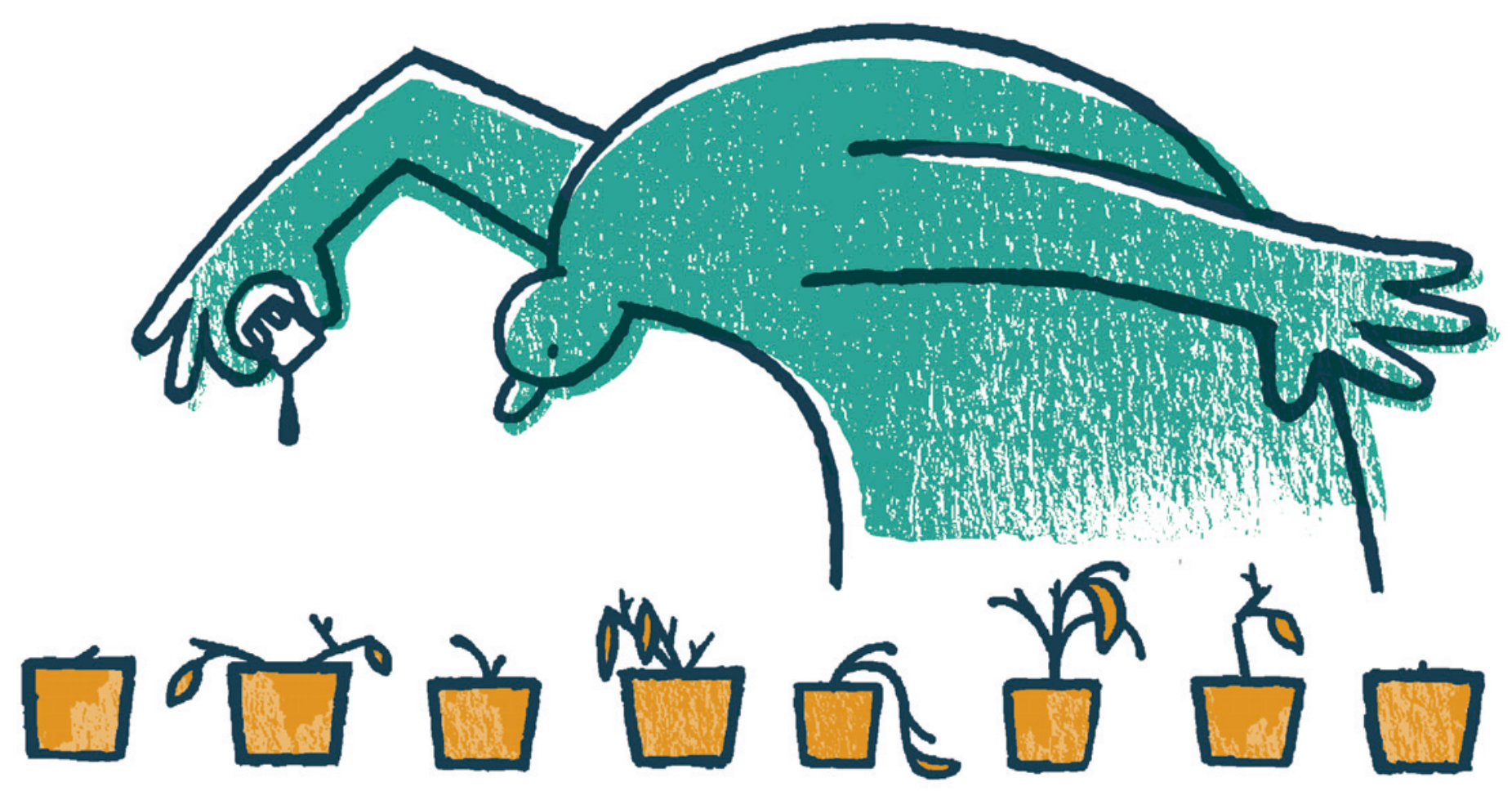

Illustrasjon @ Superpop

derimot, anbefaler at status som sjelden sykdom bør tillegges selvstendig vekt ved prioriteringer og at samfunnet bør ha høyere betalingsvilje for sjeldne sykdommer (16). Hvorvidt sjeldenhet skal vektlegges i prioriteringer, er et spørsmål som Norheimutvalget spesifikt er bedt om å vurdere.

\section{Andre prioriteringshensyn}

I en sak om robotassistert kirurgi kom det frem at bruk av robot ikke er vist å gi særlig bedre pasientbehandling, men koster vesentlig mer. I sitt vedtak sa rådet blant annet: «Det er ønskelig at norsk helsetjeneste er en arena for teknologiutvikling.» Her signaliserer rådet at innovasjon er viktig, men det blir også poengtert $i$ vedtaket at ny teknologi må tas i bruk på en mer systematisk og etterprøvbar måte. Nasjonalt råd har uttalt at helsetjenesten bør legge større vekt på at alle skal få like godt behandlingsresultat uavhengig av sosial status (17). Rådet har argumentert for at det derfor kan være riktig å gi positiv særbehandling for å motvirke sosiale helseforskjeller, både i planlegging og gjennomføring av helsetjenestetilbud.

Forebygging har de siste årene vært et tema i helsepolitikken, og Nasjonalt råd har drøftet ulike forebyggende tiltak som røykeavvenning, vaksiner og screening. Det er flere dilemmaer knyttet til prioritering av forebyggende tiltak. Dette gjenspeiles i rådets drøftinger. I Folkehelse- meldingen er det oppsummert slik: «Dersom vi forutsetter at de ressursene som går til helse, er en gitt størrelse, kan forebygging teoretisk sett ses på som å ta ressurser fra dem som i dag har problemer og overføre ressursene til friske personer» (18). Forebygging utfordrer dermed alvorlighetskriteriet. I Folkehelsemeldingen sies det videre: «Det paradoksale med dette utgangspunktet er at det over tid vil kunne føre til større tap av leveår med god helse. Videre er det problematisk at tilnærmingen ikke tar hensyn til interessene til dem som blir syke i framtiden, fordi det ikke satses på forebyggende arbeid i dag.» (18). Hvordan disse hensynene skal balanseres er en utfordring for Norheimutvalget.

\section{Oppsummering}

Gode prinsipper og kriterier for prioritering gir bedre fordeling og mer rettferdighet. Kanskje enda viktigere er det man da unngår: at det skjer usynlige prioriteringer og at prinsippet om «den sterkestes rett» vinner frem. Diskusjonene i Nasjonalt råd har vist at flere kriterier enn dagens tre er relevante for prioritering av helsetjenestens ressurser. Uansett hvilke kriterier som legges til grunn, er det vanskelig å måtte si nei til tiltak. Prioritering er krevende. Hvilket annet helseområde har hatt behov for tre offentlige utvalg for å vurdere de samme spørsmålene? Ivar Aasen har nok fortsatt mye rett: «Og kor du bryggjar og kor du bakar, d'er alltid ein, som det ikkje smakar» (1).

\section{Hege Wang (f. 1967)}

er sivilingeniør, ph.d. og seniorrådgiver ved sekretariatet for Nasjonalt råd for kvalitet og prioritering i helse- og omsorgstjenesten. Forfatter har fylt ut ICMJE-skjemaet og oppgir ingen interessekonflikter.

\section{Siv Cathrine Høymork (f. 1965)}

er spesialist i anestesiologi, ph.d., avdelingsdirektør i Kunnskapssenteret og leder sekretariatet for Nasjonalt råd for kvalitet og prioritering i helse- og omsorgstjenesten.

Forfatter har fylt ut ICMJE-skjemaet og oppgir ingen interessekonflikter.

\section{Litteratur}

1. Aasen I. Etterstev. Symra - tvo tylfter med visor og rim. 3.utg. Kristiana: P.T. Mallings Boghandel, 1875

2. Meld.St. 16 (2010-2011). Nasjonal helse-og omsorgsplan (2011-2015). www.regjeringen.no/ nb/dep/hod/dok/regpubl/stmeld/2010-2011/ meld-st-16-20102011.html?id=639794 (2.5.2014)

3. Norges offentlige utredninger. Retningslinjer for prioriteringer innen norsk helsetjeneste. NOU 1987: 23.

4. Norges offentlige utredninger. Prioritering på ny Gjennomgang av retningslinjer for prioriteringer innen norsk helsetjeneste. NOU 1997: 18 www.regjeringen.no/nb/dep/hod/dok/nouer/1997/ nou-1997-18/4.html?id=140960 (2.5.2014)

5. Føllesdal A. Bør prioritering av helsetiltak baseres på pliktetikk eller nytteetikk? Tidsskr Nor Lægeforen 2003; 123: 2897-8. 
6. Prioriteringsutvalget. http://prioriteringsutvalget. stat.no (25.2.2014).

7. Ringard A, Mørland B, Røttingen JA. Åpne prosesser for prioritering. Tidsskr Nor Legeforen 2010; 130: 2264-6.

8. Økonomisk evaluering av helsetiltak - en veileder S-1985. Oslo: Helsedirektoratet, 2012.

9. Raskere tilbake. www.nav.no/Arbeid/

Jobb+og+helse/Raskere+tilbake (25.2.2014)

10. Etablering av tidlig ultralyd i svangerskapsomsorgen. Saksdokument til Nasjonalt råd for kvalitet og prioritering i helse- og omsorgstjenesten. www.kvalitetogprioritering.no/saker/etableringav-et-offentlig-tilbud-om-tidlig-ultralyd-isvangerskapet [2.5.2014].

11. Rekonstruksjon etter brystkreftoperasjon. www.kvalitetogprioritering.no/saker/ rekonstruksjon-etter-brystkreftoperasjon (25.2.2014).

12. Behandlingsreiser til utlandet www.kvalitetogprioritering.no/saker/ behandlingsreiser-til-utlandet (25.2.2014)

13. Hvordan sikre et godt og likeverdig behandlingstilbud for sjeldne tilstander?

www.kvalitetogprioritering.no/saker/hvordansikre-et-godt-og-likeverdig-behandlingstilbudfor-sjeldne-tilstander (25.2.2014)

14. Implanterbar hjertepumpe (LVAD) som bro til hjertetransplantasjon og for varig behandling ved hjertesvikt. www. kvalitetogprioritering.no/saker/ implanterbar-hjertepumpe-lvad-som-bro-tilhjertetransplantasjon-og-for-varig-behandlingved-hjertesvikt (25.2.2014).

15. Robberstad B, Askildsen JE, Norheim OF. Styrer budsjettkonsekvens norske refusjonsprioriteringar? Tidsskr Nor Legeforen 2013; 133: 1841-3.

16. Heiberg A, Frich J, Røttingen J-A. Sjeldenhet eget kriterium ved prioritering? Tidsskr Nor Legeforen 2014; 134: 534-6.

17. Sosial ulikhet i helse - relevant for helse- og omsorgstjenesten? www.kvalitetogprioritering.no/ saker/sosial-ulikhet-i-helse-relevant-for-helseog-omsorgstjenesten (25.2.2014)

18. Meld.St. 34 (2012-2013) Folkehelsemeldingen. www.regjeringen.no/nb/dep/hod/dok/regpubl/ stmeld/2012-2013/meld-st-34-20122013.html?id= 723818 (2.5.2014).

Mottatt 21.3. 2014, første revisjon innsendt 8.4.

2014, godkjent 2.5. 2014. Redaktør: Kari Tveito. 